\title{
The Water-Soluble Chitosan Derivative, N-Methylene Phosphonic Chitosan, Is an Effective Fungicide against the Phytopathogen Fusarium eumartii
}

\author{
Florencia Anabel Mesas ${ }^{1}$, María Cecilia Terrile ${ }^{1}$, María Ximena Silveyra ${ }^{1}$, Adriana Zuñiga ${ }^{2}$, \\ María Susana Rodriguez ${ }^{2}$, Claudia Anahí Casalongué ${ }^{1 *}$, and Julieta Renée Mendieta (iD ${ }^{1 *}$ \\ ${ }^{1}$ Instituto de Investigaciones Biológicas, UE CONICET-UNMDP, Facultad de Ciencias Exactas y Naturales, Universidad \\ Nacional de Mar del Plata, Funes 3250 (7600) Mar del Plata, Argentina \\ ${ }^{2}$ INQUISUR, Departamento de Química, Universidad Nacional del Sur-CONICET, Av. Alem 1253, (8000) Bahía Blanca, \\ Argentina
}

(Received on June 6, 2021; Revised on August 22, 2021; Accepted on September 18, 2021)

Chitosan has been considered an environmental-friendly polymer. However, its use in agriculture has not been extended yet due to its relatively low solubility in water. N-Methylene phosphonic chitosan (NMPC) is a watersoluble derivative prepared by adding a phosphonic group to chitosan. This study demonstrates that NMPC has a fungicidal effect on the phytopathogenic fungus Fusarium solani f. sp. eumartii (F. eumartii) judged by the inhibition of $F$. eumartti mycelial growth and spore germination. NMPC affected fungal membrane permeability, reactive oxygen species production, and cell death. Also, this chitosan-derivative exerted antifungal effects against two other phytopathogens, Botrytis cinerea, and Phytophthora infestans. NMPC did not affect tomato cell viability at the same doses applied to these phytopathogens to exert fungicide action. In addition to water solubility, the selective biological cytotoxicity of

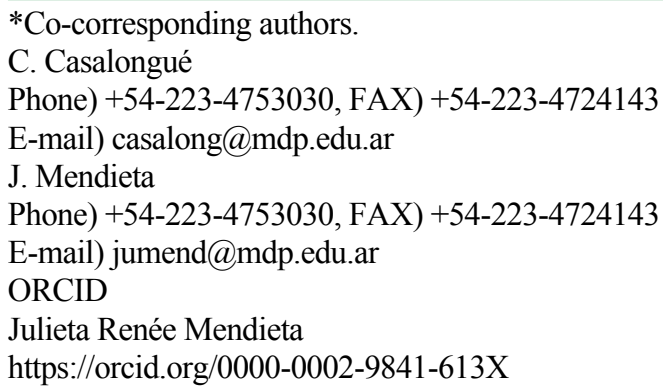

(c) This is an Open Access article distributed under the terms of the Creative Commons Attribution Non-Commercial License (http:// creativecommons.org/licenses/by-nc/4.0) which permits unrestricted noncommercial use, distribution, and reproduction in any medium, provided the original work is properly cited.

Articles can be freely viewed online at www.ppjonline.org.
NMPC adds value in its application as an antimicrobial agent in agriculture.

Keywords : antifungal activity, Fusarium solani f. sp. eumartii, N-methylene phosphonic chitosan derivative, Solanum lycopersicum

Fusarium solani f. sp. eumartii ( $F$. eumartii) is a fungus that causes dry potato rot, one of the most economically impacting diseases in the United States, Argentina, Brazil, and Canada. F. eumartii infection produces reddish-brown mottling symptoms in tubers between leaf veins and dry rot (Carpenter, 1915). Although F. eumartii has been historically considered a potato pathogen, it also infects tomato plants (Solanum lycopersicum). Chemical fungicides, such as benzilate and thiabendazole, are frequently used to control fusariosis. However, these fungicides are heavy-duty chemicals that often cause detrimental effects, including pollution and toxicity. Specifically, they produce reproductive and developmental problems in laboratory animals at high oral doses, including skeletal malformations, increased mortality in rats, and multiple anomalies in mice (Gupta, 2018). The resistance of different Fusarium spp. against several chemical fungicides has also been previously described (Hou et al., 2018; Qiu et al., 2014; Zhou and Wang, 2001). From all these issues, there is still demand for a more sustainable and eco-friendly type of fungicides and technological improvement to prevent emerging transboundary agriculture and food threats, such as pests and diseases (Food and Agriculture Organization of the United Nations, 2017). In this sense, chitosan-based polymers possess proper characteristics since they have not toxicity for 
the environment and humans (Malerba and Cerana, 2018; Maluin and Hussein, 2020).

Chitosan is a linear polysaccharide composed of randomly spread $\beta-(1-4)$ linked D-glucosamine and N-acetylD-glucosamine. This biopolymer displays three functional groups, including primary and secondary hydroxyls and an amine group. It is obtained from chitin which is abundant and easy to isolate from crustacean exoskeletons (Younes and Rinaudo, 2015). Most of the agricultural applications reported for the chitosan has been related to its capacity for the stimulation of plant innate defense mechanisms (Chakraborty et al., 2020) but, also several studies have demonstrated its antimicrobial properties against a set of fungi and bacteria (Duan et al., 2019; Wang et al., 2020). Chitosan is also helpful in controlling the population of plant pathogenic nematodes (El-Sayed and Mahdy, 2015; Fan et al., 2020; Kalaiarasan et al., 2006; Westerdahl et al., 1992). Unfortunately, one disadvantage for its wide use in agriculture is its poor water solubility (de Oliveira Pedro et al., 2013). Therefore, chitosan derivatives compounds have been considered in terms of solubility, gelling, amphiphilic hydrophobic properties, and enhanced biocompatibility when compared to unmodified chitosan (Sahariah \& Már Másson). The derivatization has been a widely used procedure to improve the physicochemical properties of chitosan-based compounds (Verlee et al., 2017). The synthesis of $O-, N$ - or $N, O$-substituted derivatives has been extensively studied (Argüelles-Monal et al., 2018). Heras et al. (2001) described the obtention of the water-soluble Nmethylene phosphonic chitosan (NMPC) by reacting chitosan with a phosphonic group. NMPC is soluble in water over a wide range of $\mathrm{pH}$ values, and it is a $\mathrm{Ca}^{2+}$ and transition metal chelator (Ramos et al., 2003). NMPC was described as a non-viral gene carrier in HeLa cells, indicating its high potential in clinical applications (Zhu et al., 2007). However, so far, it has not been demonstrated to have antimicrobial properties on any pathogenic microorganisms. In this work, we demonstrated the NMPC-mediated antimicrobial action on different phytopathogens such as $F$. eumartii, Botrytis cinerea, and Phytophthora infestans. In addition, we studied cellular and biochemical downstream events associated with the mode of action of NMPC on the phytopathogen $F$. eumartii. The antifungal effects on these phytopathogens and the minimal cytotoxicity compared on plant cells suggest that NMPC may be an effective alternative treatment for phytopathogens in agriculture.

\section{Materials and Methods}

Biological materials. Estación Experimental Agropecuaria
(EEA) INTA, Balcarce (Argentina) provided the isolated 3122 from $F$. eumartii (Radtke and Escande, 1973). This fungus was grown on solid potato dextrose agar (PDA; Merck, Darmstadt, Germany) medium at $25^{\circ} \mathrm{C}$ in darkness. Spores from 8-day-old culture plates were collected and suspended in sterile distilled water (Terrile et al., 2015). $B$. cinerea strain B05.10 was cultured as described by Benito et al. (1998). P. infestans mating type A2 was grown and preserved on fresh potato tuber slices (Andreu et al., 2010).

Tomato cell suspensions (S. lycopersicum cv. Money Maker, line Msk8) were grown in Murashige-Skoog medium described by Laxalt et al. (2007).

NMPC preparation. The chitin, chitosan, and NMPC were prepared as described by Heras et al. (2001). Briefly, chitosan $(2 \% \mathrm{w} / \mathrm{v})$ was dissolved in $1 \%(\mathrm{v} / \mathrm{v})$ glacial acetic acid. Equals parts of chitosan and phosphorous acid (w/ w) were mixed drop-wise with continuous stirring for $1 \mathrm{~h}$. Then, an equal part of $36.5 \%(\mathrm{w} / \mathrm{v})$ formaldehyde was added drop-wise for an additional $1 \mathrm{~h}$ with reflux at $70^{\circ} \mathrm{C}$. The clear pale yellow solution was dialyzed against distilled water in dialysis tubing with a cut-off value of 2,500 Da for $48 \mathrm{~h}$ or until the $\mathrm{pH}$ of the water was raised to 6.8 . Finally, the solution was frozen and freeze-dried. The characteristics of NMPC used in this study are $615,595 \mathrm{Da}$, viscosity $22.5 \mathrm{mPa} / \mathrm{seg}$, substitution degree 1.54 , elemental analysis (\%) C, 34.68; H, 7.10; N, 5.15; P, 7.93. The solubility of NMPC in aqueous media over an extended $\mathrm{pH}$ range and its filmogenic nature was verified as previously described (Heras et al., 2001).

Measurements of spore and sporangium germination. The antifungal activity of NMPC on $F$. eumartii and $B$. cinerea spores and $P$. infestans sporangia was evaluated as described by Mendieta et al. (2006). F. eumartii $\left(1 \times 10^{6}\right.$ spores $/ \mathrm{ml})$ and $B$. cinerea spores $\left(1 \times 10^{5}\right.$ spores $\left./ \mathrm{ml}\right)$, and $P$. infestans sporangia $\left(5 \times 10^{4}\right.$ sporangia $\left./ \mathrm{ml}\right)$ were treated with different concentrations of NMPC $(0.5,1,1.5,2.5,5$, and $10 \mu \mathrm{g} / \mathrm{ml}$ ) in a final volume of $50 \mu 1$ of $1 \%$ sucrose and put on micro slides. The spores of $F$. eumartii and $B$. cinerea were incubated at $25^{\circ} \mathrm{C}$, while $P$. infestans sporangia at $18^{\circ} \mathrm{C}$ for $24 \mathrm{~h}$ in darkness. Germinated spores and sporangia were quantified in a hemocytometer under a light microscope Eclipse E200 (Nikon, Tokyo, Japan). We considered spores and sporangia germinated when the germ tube length was longer than one-half of the reproductive structure (Plascencia-Jatomea et al., 2003). We analyzed at least 250 spores or sporangia per replicate, with 3 replicates per treatment. We estimated the $\mathrm{IC}_{50}$ values as the concentration of NMPC that reduce germination by $50 \%$. 
Inhibition of $F$. eumartii mycelial growth. Final concentrations $(5,50,100$, or $500 \mu \mathrm{g} / \mathrm{ml})$ of NMPC were incubated with $0.5 \mathrm{~cm}$-diameter disks of PDA agar containing $F$. eumartii mycelia in flasks containing $100 \mathrm{ml}$ of fresh potato dextrose broth medium. $F$. eumartti was grown at $25^{\circ} \mathrm{C}$ with shaking at $100 \mathrm{rpm}$ in darkness. After 4 days, fungal culture was filtered through muslin to get mycelia and placed in an oven at $65^{\circ} \mathrm{C}$ for $3 \mathrm{~h}$. The mycelial-dry biomass was measured, and the $\mathrm{IC}_{50}$ value was estimated.

Fungicidal activity on $\boldsymbol{F}$. eumartii cells. $F$. eumartii spores $\left(1 \times 10^{4}\right.$ spores $\left./ \mathrm{ml}\right)$ were treated with 1 and $5 \mu \mathrm{g} /$ $\mathrm{ml}$ of NMPC or distilled water in a final volume of 60 $\mu 1$. Samples were incubated at $25^{\circ} \mathrm{C}$ for $24 \mathrm{~h}$ in darkness and then spread on PDA. After 3 days, the colonies were counted, and the number of colony-forming units (cfu) was calculated in each sample.

F. eumartii cell viability assay. $F$. eumartii cell viability was determined by propidium iodide (PI; Sigma-Aldrich, St. Louis, MO, USA) exclusion as described by Terrile et al. (2015). PI is used to evaluate cell viability as a nucleic acids stain. Once the dye is bound to nucleic acids, its fluorescence is enhanced 20-30-fold (Novo et al., 2000). F. eumartii spores $\left(1 \times 10^{6}\right.$ spores $\left./ \mathrm{ml}\right)$ were treated with 1 and $5 \mu \mathrm{g} / \mathrm{ml}$ of NMPC at $25^{\circ} \mathrm{C}$ for $24 \mathrm{~h}$ in darkness. PI was added at a final concentration of $120 \mu \mathrm{M}$, and the $F$. eumartii spores were observed in an Eclipse E200 microscope (Nikon) with a G-2E/C filter set containing an excitation filter at $540 / 25 \mathrm{~nm}$, suppressor filter at $630 / 60 \mathrm{~nm}$, and a dichroic mirror at $565 \mathrm{~nm}$.

Membrane permeabilization assay. We detected fungal cells with compromised cell membranes by recording the fluorescence of the DNA-binding dye SYTOX Green (Molecular Probes, Eugene, OR, USA). Permeabilization of the fungal membrane allows the dye to cross the membranes and to intercalate into the DNA. This association displays an intense fluorescence emission when it is excited by blue light illumination (Rioux et al., 2000). The spores were incubated with $5 \mu \mathrm{g} / \mathrm{ml}$ of NMPC or distilled water at $25^{\circ} \mathrm{C}$ for 1,2 , and $4 \mathrm{~h}$ in darkness. Next, $1 \mu \mathrm{M}$ of SYTOX Green (Invitrogen) was added, and immediately the spores were observed with an Eclipse E200 fluorescence microscope equipped with a B-2 A fluorescein filter set (Nikon).

Measurements of endogenous $\mathrm{H}_{2} \mathrm{O}_{2}$. The endogenous $\mathrm{H}_{2} \mathrm{O}_{2}$ level was assessed by peroxidase-dependent staining using 3,3'-diaminobenzidine (DAB; Merck). DAB polymerizes in contact with $\mathrm{H}_{2} \mathrm{O}_{2}$ in the presence of peroxidase, producing an insoluble colored complex (Thordal-Christensen et al., 1997). F. eumartii spores at a final concentration of $1.5 \times 10^{6}$ spores $/ \mathrm{ml}$ were incubated with 2.5 and 5 $\mu \mathrm{g} / \mathrm{ml}$ of NMPC at $25^{\circ} \mathrm{C}$ for $4 \mathrm{~h}$. Then, $0.5 \mathrm{mg} / \mathrm{ml}$ of DAB was added to each sample and incubated for an additional $1 \mathrm{~h}$ before rinsing. The spores were observed under an Eclipse E200 light microscope (Nikon).

Tomato cell viability assay. Tomato cell suspensions were grown in Murashige-Skoog medium (Duchefa, Haarlem, The Netherlands) supplemented with $5.4 \mathrm{M}$ naphthalene acetic acid, 1 M 6-benzyladenine, and vitamins (Duchefa) at $24^{\circ} \mathrm{C}$ with continuous agitation in darkness as described by Laxalt et al. (2007). Tomato cell viability was assayed by Evans blue staining (Sukenik et al., 2018). The cells were incubated with 10 and $100 \mu \mathrm{g} / \mathrm{ml}$ of NMPC at $30^{\circ} \mathrm{C}$ for $24 \mathrm{~h}$ in darkness. As a positive control, cells were treated with $1 \%$ Triton X-100 (v/v). Twenty-five $\mu 1$ of $1 \%$ Evans blue solution were added to $50 \mu 1$ of treatedsuspension cells, incubated at room temperature for $5 \mathrm{~min}$, and observed under Eclipse E200 light microscope (Nikon). The extent of dye uptake by dead cells was quantified spectrophotometrically by incubating $250 \mu$ l of each suspension with $150 \mu 11 \%$ Evans blue for $5 \mathrm{~min}$ at room temperature. Unbound Evans blue stain was removed by washing four times with $0.1 \mathrm{M}$ Tris- $\mathrm{HCl} \mathrm{pH}$ 7.5. Cells were collected by centrifuging at $800 \mathrm{rpm}$ for $15 \mathrm{~s}$ and lysed with $250 \mu \mathrm{l}$ $100 \%$ dimethyl sulfoxide (Sigma-Aldrich) at $100^{\circ} \mathrm{C}$ for 15 min. The absorbance at $595 \mathrm{~nm}$ was measured by using a microplate reader ELx800 (BioTek, Winooski, VT, USA).

Statistical analysis. The values shown in each figure are the mean values \pm SD of at least 3 experiments. Data were subjected to analysis of variance (one-way ANOVA) and post hoc comparisons with Tukey's multiple range test at $P$ $<0.05$ level. GraphPad Prism 5 (GraphPad Software Inc., San Diego, CA, USA) was used as a statistical software program.

\section{Results}

NMPC is an antifungal chitosan derivative. As a first approach to evaluate the antifungal effect of NMPC, we incubated $F$. eumartii and $B$. cinerea spores and $P$. infestans sporangia with different concentrations of NMPC for $24 \mathrm{~h}$. We observed that NMPC inhibited the germination of different cell types in a dose-dependent manner, with almost $100 \%$ of spores and sporangia inhibited at $10 \mu \mathrm{g} / \mathrm{ml} \mathrm{NMPC}$ (Fig. 1A and B). The estimated $\mathrm{IC}_{50}$ values for $F$. eumartii, B. cinerea, and $P$. infestans were $2.5 \pm 0.9,4 \pm 1.2$, and 2 
A

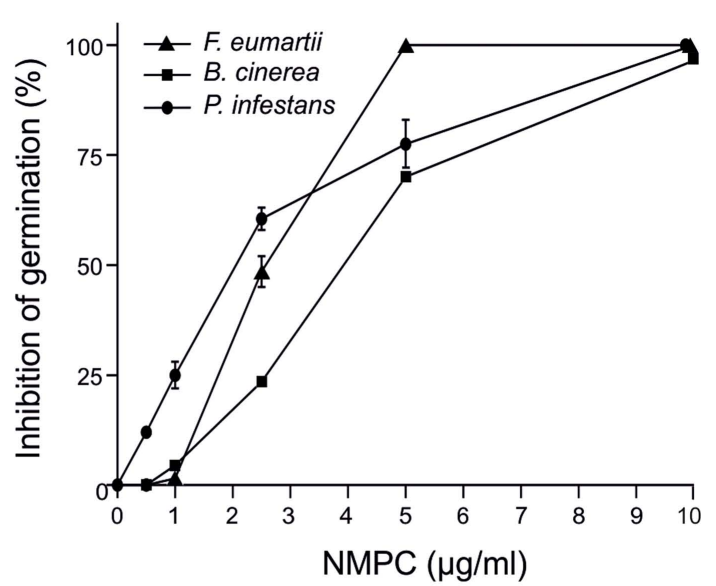

B

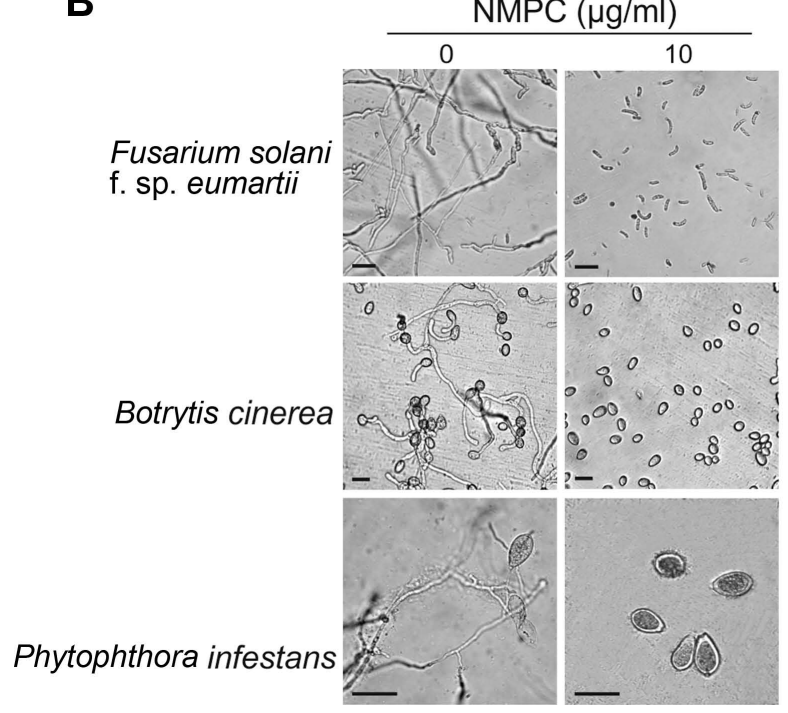

Fig. 1. Antimicrobial dose-dependent effect of N-methylene phosphonic chitosan (NMPC). (A) The values represent the percentages of total spores/sporangia present in each sample after the incubation with different concentrations of NMPC for $24 \mathrm{~h}$. Each value is the mean $\pm \mathrm{SD}$ of at least 3 independent experiments. (B) Representative images are shown. Scale bars $=22 \mu \mathrm{m}$ (upper panels), $15 \mu \mathrm{m}$ (middle panels), $30 \mu \mathrm{m}$ (lower panels).

$\pm 1.3 \mu \mathrm{g} / \mathrm{ml}$, respectively. The $\mathrm{IC}_{50}$ value of NMPC) on $F$. eumartii was similar to the $\mathrm{IC}_{50}$ obtained when chitosan was used as control $(4.3 \pm 2.3 \mu \mathrm{g} / \mathrm{ml})$ (Supplementary Fig. 1). This fact allowed us to deep into the action of NMPC as a water-soluble and antifungal agent on $F$. eumartii cells currently used as a phytopathogen model. NMPC caused a significant dose-dependent inhibition of mycelial growth, with a dry mass reduction nearly to $60 \%$ at $50 \mu \mathrm{g} / \mathrm{ml}$ of NMPC compared to control (Fig. 2). In this case, the estimated $\mathrm{IC}_{50}$ for mycelial growth was $22 \pm 5.2 \mu \mathrm{g} / \mathrm{ml}$, almost 9 times higher than the estimated $\mathrm{IC}_{50}$ value for $F$. eumartii

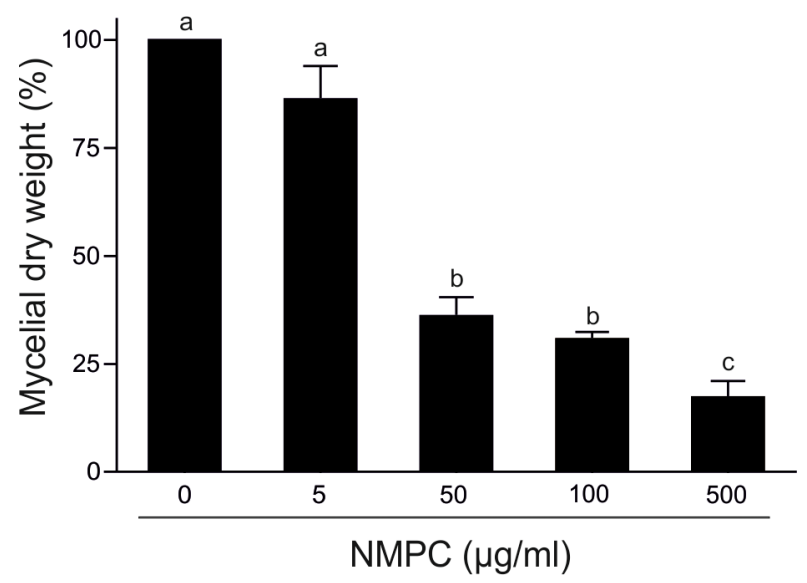

Fig. 2. N-Methylene phosphonic chitosan (NMPC) inhibits $F u$ sarium solani $\mathrm{f}$. sp. eumartii ( $F$. eumartii) mycelial growth. $F$. eumartii was inoculated in a liquid potato dextrose broth medium with different concentrations of NMPC and incubated for 4 days. The quantification of the mycelial-dry weight is expressed as the percentage of control (100\%). Each value is the mean $\pm \mathrm{SD}$ of 3 independent experiments. Different letters point out statistically significant differences (Tukey's test, $P<0.05$ ).

spore germination.

To study the fungicidal effect, we incubated $F$. eumartii spores with different concentrations of NMPC for $24 \mathrm{~h}$ and then plated them on an NMPC-free PDA medium for 3

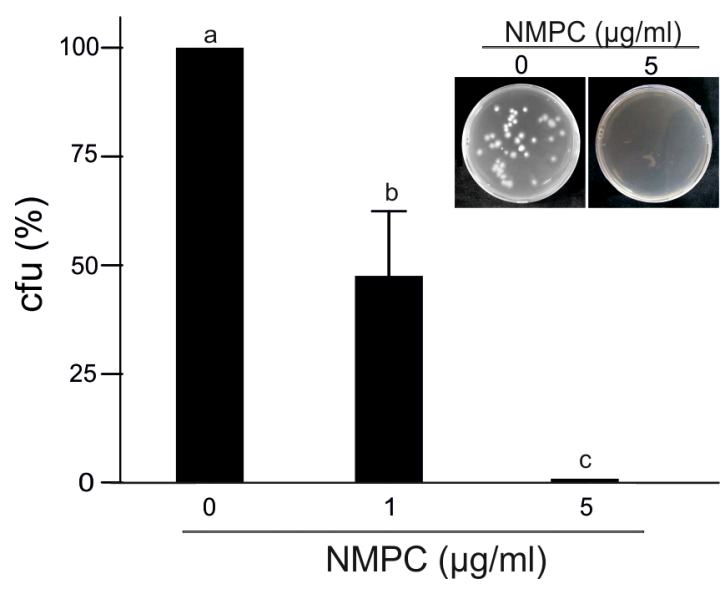

Fig. 3. N-Methylene phosphonic chitosan (NMPC) mediates fungicidal action on Fusarium solani f. sp. eumartii (F. eumartii) spores. Spores were incubated with 1 or $5 \mu \mathrm{g} / \mathrm{ml} \mathrm{NMPC} \mathrm{for} 24$ $\mathrm{h}$ and then plated on the Petri dishes containing fresh potato dextrose agar media to allow fungal growth. F. eumartti was grown for 3 days at $25^{\circ} \mathrm{C}$. Values represent the percentage of colonyforming units compared to control $(100 \%)$. Each value is the mean \pm SD of at least 3 independent experiments. Different letters point out statistically significant differences (Tukey's test, $P$ $<0.05)$. Representative images are shown (inset). 
A

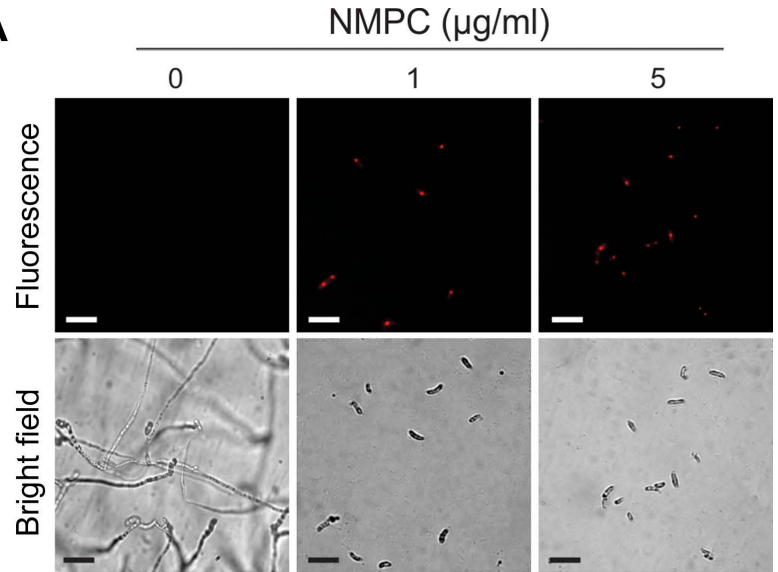

B

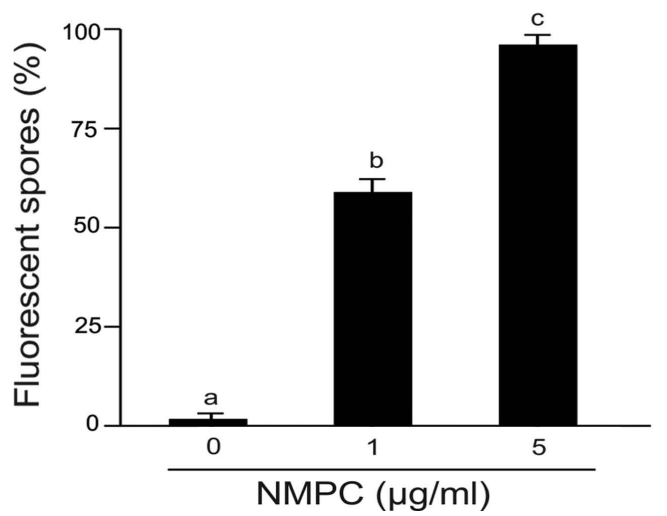

Fig. 4. N-Methylene phosphonic chitosan (NMPC) affects Fusarium solani f. sp. eumartii ( $F$. eumartii) cell viability. Fungal spores were incubated with $1 \mu \mathrm{g} / \mathrm{ml}$ or $5 \mu \mathrm{g} / \mathrm{ml} \mathrm{NMPC}$ for 24 $\mathrm{h}$ and stained with propidium iodide. Dead spores are observed in red fluorescence. (A) Representative images are shown. The bright-field image for each treatment is shown below the respective fluorescent images. Scale bars $=22 \mu \mathrm{m}$. (B) Values represent the percentage of the stained spores present in each sample. Each value is the mean $\pm \mathrm{SD}$ of at least 3 independent experiments Different letters point out statistically significant differences (Tukey's test, $P<0.05$ ).

days. Interestingly, the incubation with $5 \mu \mathrm{g} / \mathrm{ml}$ of NMPC almost abolished fungal growth, suggesting a sensitive NMPC-mediated fungicidal action (Fig. 3). As shown in Fig. 4, while control spores remained unstained by PI, a dose-dependent increase in the percentage of PI-positive spores was observed in NMPC treated $F$. eumartii cells. We detected the highest toxicity $(91.3 \%)$ at $5 \mu \mathrm{g} / \mathrm{ml} \mathrm{NMPC}$ (Fig. 4B)

NMPC triggers membrane permeabilization and endogenous $\mathrm{H}_{2} \mathrm{O}_{2}$ in $F$. eumartii cells. We analyzed the cell membrane integrity of $F$. eumartii spores by using SYTOX Green. Spores incubated with $5 \mu \mathrm{g} / \mathrm{ml}$ of NMPC during

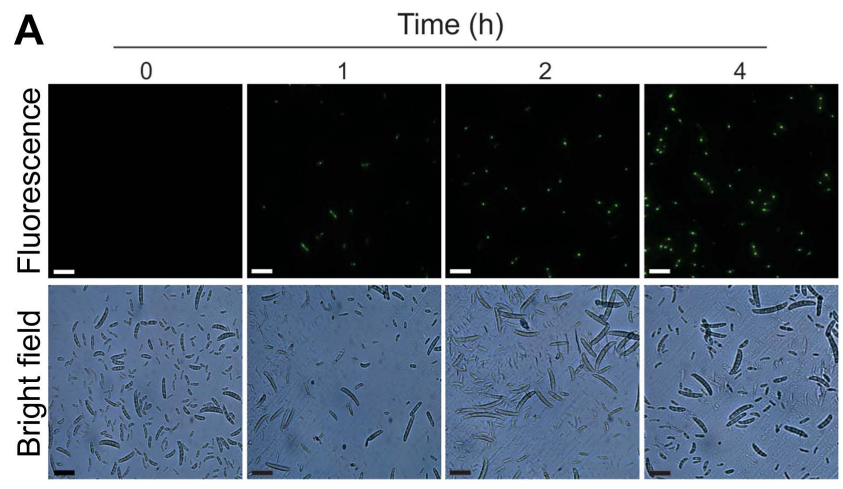

B

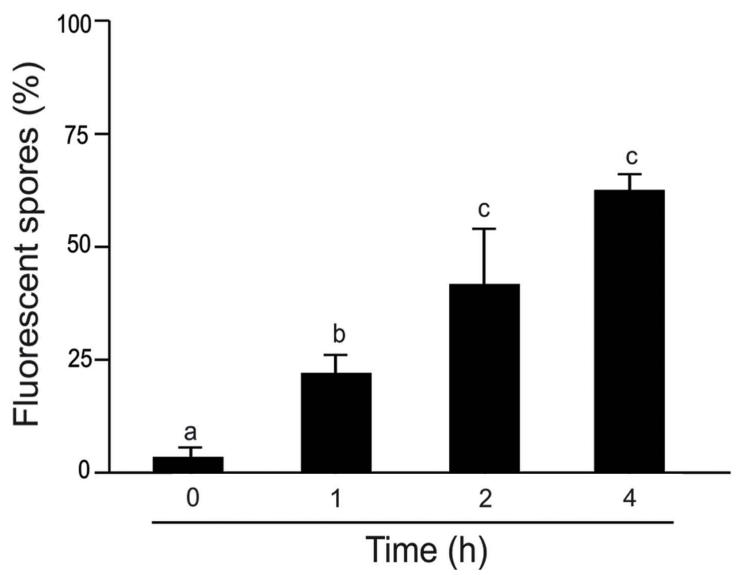

Fig. 5. N-Methylene phosphonic chitosan (NMPC) induces cell membrane permeabilization. Kinetic of cell membrane permeabilization by $5 \mu \mathrm{g} / \mathrm{ml}$ NMPC in fungal spores. Cell membrane permeabilization was visualized in Fusarium solani f. sp. eumartii (F. eumartii) spores by SYTOX Green probe. (A) Representative images are shown. Scale bars $=22 \mu \mathrm{m}$. (B) Values represent the percentage of green spores present in each sample. Each value is the mean \pm SD of at least 3 independent experiments. Different letters point out statistically significant differences (Tukey's test, $P<0.05)$

different times were stained with SYTOX Green and subjected to microscopic analysis. Fig. 5A shows that SYTOX Green-mediated fluorescent spores increased over time. While control spores remained virtually unstained, $22 \%$ of spores displayed green-fluorescence at $1 \mathrm{~h}$ after treatment, and $65 \%$ of them were positive for SYTOX Green at $4 \mathrm{~h}$ after initial treatment (Fig. 5B). Next, NMPC-mediated cytotoxicity was explored by measuring endogenous $\mathrm{H}_{2} \mathrm{O}_{2}$ production in $F$. eumartii spores. The levels of $\mathrm{H}_{2} \mathrm{O}_{2}$ gradually increased in a dose-dependent manner by NMPC treatment. After $4 \mathrm{~h}$ of $5 \mu \mathrm{g} / \mathrm{ml}$ NMPC treatment, $98 \%$ of spores were stained, compared with the untreated control (Fig. 6). These findings indicated that cell membrane permeabilization and $\mathrm{H}_{2} \mathrm{O}_{2}$ production are triggered by NMPC 
A

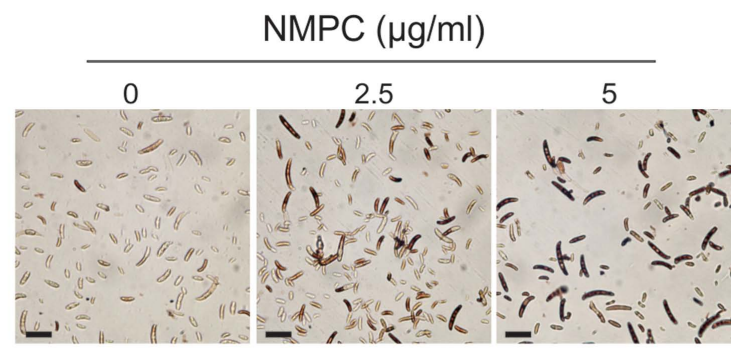

B

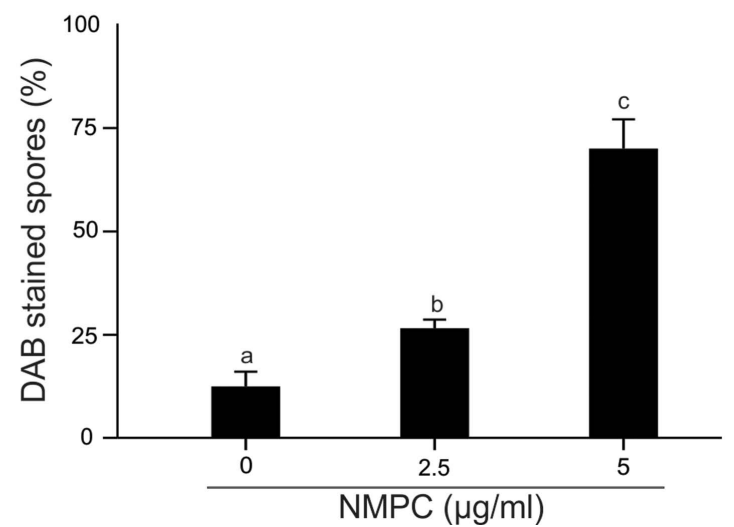

Fig. 6. N-Methylene phosphonic chitosan (NMPC) induces $\mathrm{H}_{2} \mathrm{O}_{2}$ production in Fusarium solani f. sp. eumartii ( $F$. eumartii) spores. Spores were treated with 2.5 or $5 \mu \mathrm{g} / \mathrm{ml} \mathrm{NMPC} \mathrm{for} 4$ $\mathrm{h}$ before 3,3'-diaminobenzidine (DAB) staining and subjected to microscopic analysis. (A) Representative images are shown. Scale bars $=22 \mu \mathrm{m}$. (B) Values are expressed as a percentage of total spores present in each sample. Each value is the mean \pm SD of at least 3 independent experiments. Different letters point out statistically significant differences (Tukey’s test, $P<0.05$ ).

treatment, and these events could promote the death of $F$. eumartii spores.

NMPC does not affect tomato cell viability. Considering NMPC as a putative antimicrobial agent with potential application in plants, we studied its toxicity on tomato cells. We incubated tomato cell suspension cultures with 10 and $100 \mu \mathrm{g} / \mathrm{ml}$ NMPC for $24 \mathrm{~h}$. Then cells were stained with the vital dye Evans blue. The quantification of dye uptake showed that cell viability did not significantly decrease after incubation with 10 and $100 \mu \mathrm{g} / \mathrm{ml} \mathrm{NMPC} \mathrm{(Fig.} \mathrm{7B).}$ Most tomato cells were unstained with $10 \mu \mathrm{g} / \mathrm{ml} \mathrm{NMPC}$ (93\%). Even at $100 \mu \mathrm{g} / \mathrm{ml} \mathrm{NMPC}$, the majority of tomato cells excluded the dye $(85 \%)$, and their morphology remained unchanged (Fig. 7A). However, control cells treated with 1\% Triton X-100 showed nuclei and cytoplasm fully stained, and the cell size seemed smaller than those treated either with water or NMPC (Fig. 7A). The viability of cells incubated with Triton X-100 was 7\% compared with $98 \%$ in untreated cells (Fig. 7B).
A

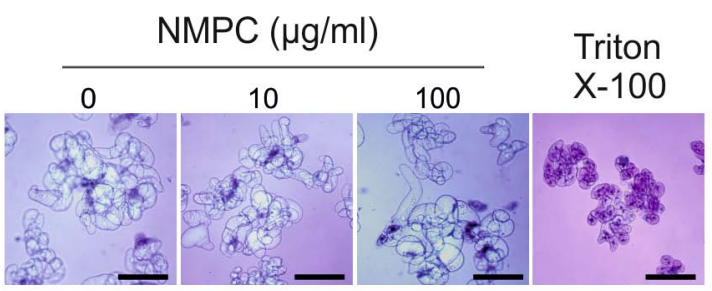

B

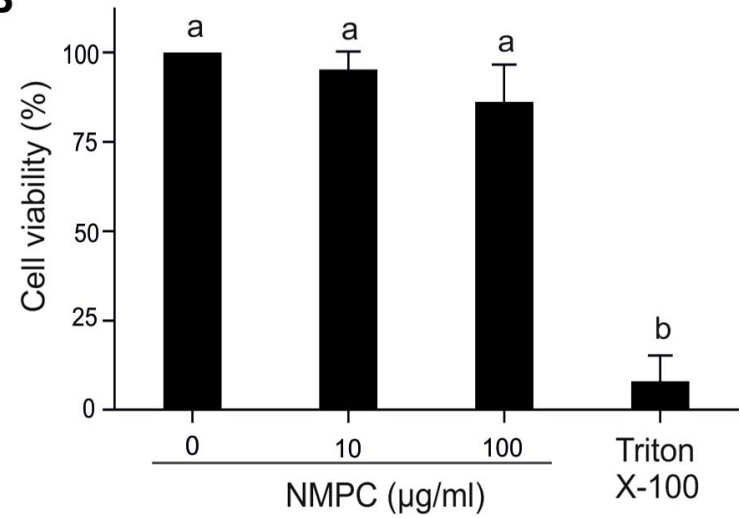

Fig. 7. N-Methylene phosphonic chitosan (NMPC) does not affect tomato cell viability. Suspension-cultured tomato cells were incubated with different concentrations of NMPC for $24 \mathrm{~h}$ and then stained with Evans blue. As negative and positive controls, water and 1\% Triton X-100 respectively, were included. (A) Representative images of at least 3 independent experiments are shown. Scale bars $=20 \mu \mathrm{m}$. (B) Quantification of cell viability was estimated by recording Evans blue retention in tomato cells. Values are expressed as the percentage of water control (100\%). Each value is the mean \pm SD of at least 3 independent experiments. Different letters point out statistically significant differences (Tukey's test, $P<0.05$ ).

\section{Discussion}

This study demonstrated that NMPC exerted antimicrobial activity on various phytopathogens with agricultural and economic relevance. According to estimated $\mathrm{IC}_{50}$ values, NMPC displayed antifungal action at similar doses on different pathogens: $F$. eumartii, $B$. cinerea, and $P$. infestans. In particular, NMPC caused cell membrane damage and loss of cell viability on $F$. eumartii spores. Interestingly, NMPC concentrations needed to reach sublethal doses in F. eumartii spores were significantly lower than those previously reported for a chitosan $\mathrm{N}$-derivative (Eweis et al., 2006; Liu et al., 2018; Wei et al., 2019; Zhang et al., 2020). Previously, Ippolito et al. (2017) reported that the synthetic fungicide Mancozeb presented antifungal action on $F$. eumartii spore germination. These effects observed with Mancozeb are similar to NMPC antifungal activity on 
F eumartti. In plants, F. eumartii infection involves spore attachment and germination before host penetration, lesion formation, and tissue maceration (Prins et al., 2000). Thus, the effect of NMPC becomes of particular importance since the progress of the infection to successfully thrive plant tissues needs the efficient germination of spores and the formation of infective hyphae (Laluk and Mengiste, 2010). F. eumartii hyphae proved to be sensitive to the antifungal compound with an estimated $\mathrm{IC}_{50}$ value of 22 $\mu \mathrm{g} / \mathrm{ml}$ NMPC. However, F. eumartii spore germination registered an $\mathrm{IC}_{50}$ much lower $(2.5 \mu \mathrm{g} / \mathrm{ml})$, indicating its differential behavior and cell-specific sensitivity. In agreement, mycelium and spores differential sensitivities have been demonstrated for other chitosans (Bautista-Baños et al., 2006; Terrile et al., 2015). The spore germination of $F$. oxysporum has resulted in more sensitivity to $\mathrm{N}$-derivative chitosan $\mathrm{N}-/ 2$ (3)-(dodec-2-enyl) succinyl than hyphal growth, being the $\mathrm{IC}_{50}$ values nearly to $5 \mu \mathrm{g} / \mathrm{ml}$ and 1,000 $\mu \mathrm{g} / \mathrm{ml}$, respectively (Tikhonov et al., 2006). A similar effect on $F$. oxysporum spore and mycelial treated with six different quaternary $\mathrm{N}$-alkyl chitosan derivatives was also described (Badawy, 2010). An explanation could be that the lipid membrane composition of fungal cells is a crucial point related to sensitivity to chitosan. Feofilova et al. (2015) reported that linoleic acid predominates in mycelial cells while oleic acid is more abundant in spores of different members of the Penicillium genus, supporting the notion that the actively growing fungal cellular structures contain more unsaturated lipids than those under exogenous dormancy. It has been demonstrated that the ratio between oleic and linoleic acids is higher in conidia from $F$. oxysporum and F. roseum than in mycelia (Rambo and Bean, 1969). Thus, we hypothesized that the differential sensitivity of $F$. eumartii cells to NMPC could be related to the different lipid compositions of each cell. Palma Guerrero et al. (2010) demonstrated that the plasma membranes of other chitosan-sensitive fungi are more abundant in polyunsaturated fatty acids than chitosan-resistant fungi. A Neurospora crassa mutant with depletion of polyunsaturated fatty acids and reduced membrane fluidity showed increased resistance to chitosan, suggesting that cell permeabilization by chitosan may be dependent on membrane fluidity.

In addition, the mechanism of action of chitosan and derivatives could also be linked to its capacity to chelate certain necessary nutrients, trace elements, and metal ions required for fungal growth (Qin et al., 2008; Rabea et al., 2003). NMPC has an aminoalkyl phosphonic ligand with chelating properties (Heras et al., 2001). Ramos et al. (2003) also proved that NMPC is a powerful chelating agent of
$\mathrm{Ca}^{2+}$ and other ions. Thus, we cannot discard that NMPC as a chelator compound could also affect $\mathrm{Ca}^{2+}$ levels in $F$. eumartii cells. Kim et al. (2015) demonstrated the $\mathrm{Ca}^{2+}$ requirement in fungal developmental processes such as germination, hyphae development, and nutrient uptake. The role of different $\mathrm{Ca}^{2+}$ channels in controlling spore germination and hyphal growth in $F$. oxysporum cells was also demonstrated (Kim et al., 2018). In the same sense, the antimicrobial action against Aspergillus flavus and $A$. parasiticus correlated with the chelation effect of N-carboxymethyl chitosan by disturbing the uptake of nutritional divalent ions (Cuero et al., 1991). However, whether the potent fungicidal action of NMPC involves chelation of $\mathrm{Ca}^{2+}$ or other ions needs to be explored.

In $F$. eumartii spores, NMPC-mediated cell membrane permeabilization was also concomitant with endogenous ROS production. Thus, cellular $\mathrm{H}_{2} \mathrm{O}_{2}$ induction may result from the primary effect of cell membrane permeabilization. Moreover, ROS production could cause lipids peroxidation of polyunsaturated fatty acids consequently, inducing cell membrane permeabilization (Howlett and Avery, 1997). In summary, cellular and biochemical events could be responsible for the loss of $F$. eumartii cell viability mediated by NMPC. Like NMPC, the chitosan derivatives, ATMCS and ATPECS inducted cell membrane damage on $F$. oxysporum hyphae (Qin et al., 2014). Recently, Lopez-Moya et al. (2021) reported that chitosan induces damages to the plasma membrane in the rice phytopathogen Magnaporthe oryzae and influences NADPH oxidase-dependent synthesis ROS, which is essential for fungal pathogenicity. NMPC could also bind to the negative charge of the membrane surface, causing permeabilization in F. eumartii spores. This fact would be supported by the fact that the current hypothesis that explains the antimicrobial action of chitosan relies on its positive charges that enable electrostatic interactions with the negative charging of the pathogen surface, thus increasing membrane permeability and resulting in cell death (Maluin and Hussein, 2020).

Interestingly, lethal doses of NMPC on $F$. eumartii did not exert toxicity in tomato cells. Considering the potential of NMPC as a fungicide, its harmlessness to plant cells is a crucial feature. In support of these findings, Asgari-Targhi et al. (2018) analyzed the effect of bulk and nano-chitosan on the growth of the Capsicum annuum. These authors demonstrate that the application of chitosan-based compounds resulted in non-phytotoxic and extended growth of the seedlings. In the same sense, the application of chitosan nanoparticles on wheat and barley showed similar results (Behboudi et al., 2017).

In conclusion, the findings show that NMPC would be 
a promising eco-friendly biofungicide to protect tomato plants against different phytopathogens. Its application could mitigate the broad use of chemical pesticides by ensuring low plant and environmental toxicity.

\section{Conflicts of Interest}

No potential conflict of interest relevant to this article was reported.

\section{Acknowledgments}

This research was supported by the Agencia Nacional de Promoción Científica y Tecnológica (PICT RAICES 0959), Universidad Nacional de Mar del Plata (EXA 928/19), Consejo Nacional de Investigaciones Científicas y Técnicas (CONICET) and Comisión de Investigaciones Científicas (CIC, 1480/18). FAM is a PhD fellow from CONICET. CAC, MCT and MXS are members of the research staff from CONICET. JRM is researcher from CIC. We thank Dr. Candela Lobato and Dr. Ana Laxalt for providing us fungal strains and tomato cells, respectively. We also thank Dr. Diego Fiol and Dr. Rubén D. Conde for his critical reading of our manuscript.

This study was funded by Agencia Nacional de Promoción Científica y Tecnológica (PICT RAICES 0959), Universidad Nacional de Mar del Plata (EXA 928/19), CONICET and Comisión de Investigaciones Científicas de la Provincia de Buenos Aires (CIC, 1480/18).

\section{Electronic Supplementary Material}

Supplementary materials are available at The Plant Pathology Journal website (http://www.ppjonline.org/).

\section{References}

Andreu, A. B., Caldiz, D. O. and Forbes, G. A. 2010. Phenotypic expression of resistance to Phytophthora infestans in processing potatoes in Argentina. Am. J. Potato Res. 87:177-187.

Argüelles-Monal, W. M., Lizardi-Mendoza, J., Fernández-Quiroz, D., Recillas-Mota, M. T. and Montiel-Herrera, M. 2018. Chitosan derivatives: introducing new functionalities with a controlled molecular architecture for innovative materials. Polymers 10:342.

Asgari-Targhi, G., Iranbakhsh, A. and Ardebili, Z. O. 2018. Potential benefits and phytotoxicity of bulk and nano-chitosan on the growth, morphogenesis, physiology, and micropropagation of Capsicum annuum. Plant Physiol. Biochem. 127:393-402.

Badawy, M. E. I. 2010. Structure and antimicrobial activity re- lationship of quaternary $N$-alkyl chitosan derivatives against some plant pathogens. J. Appl. Polym. Sci. 117:960-969.

Bautista-Baños, S., Hernández-Lauzardo, A. N., Velázquez-del Valle, M. G., Hernández-López, M., Ait Barka, E., BosquezMolina, E. and Wilson, C. L. 2006. Chitosan as a potential natural compound to control pre and postharvest diseases of horticultural commodities. Crop Prot. 25:108-118.

Behboudi, F., Tahmasebi Sarvestani, Z., Kassaee, M. Z., Modares Sanavi, S. A. M. and Sorooshzadeh, A. 2017. Phytotoxicity of chitosan and $\mathrm{SiO} 2$ nanoparticles to seed germination of wheat (Triticum aestivum L.) and barley (Hordeum vulgare L.) plants. Not. Sci. Biol. 9:242-249.

Benito, E. P., ten Have, A., van't Klooster, J. W. and van Kan, J. A. L. 1998. Fungal and plant gene expression during synchronized infection of tomato leaves by Botrytis cinerea. Eur. J. Plant Pathol. 104:207-220.

Carpenter, C. W. 1915. Some potato tuber-rots caused by species of Fusarium. J. Agric. Res. 5:183-210.

Chakraborty, M., Hasanuzzaman, M., Rahman, M., Khan, M. A. R., Bhowmik, P., Mahmud, N. U., Tanveer, M. and Islam, T. 2020. Mechanism of plant growth promotion and disease suppression by chitosan biopolymer. Agriculture 10:624.

Cuero, R. G., Osuji, G. and Washington, A. 1991. N-carboxymethylchitosan inhibition of aflatoxin production: role of zinc. Biotechnol. Lett. 13:441-444.

de Oliveira Pedro, R., Takaki, M., Gorayeb, T. C. C., Del Bianchi, V. L., Thomeo, J. C., Tiera, M. J. and de Oliveira Tiera, V. A. 2013. Synthesis, characterization and antifungal activity of quaternary derivatives of chitosan on Aspergillus flavus. Microbiol. Res. 168:50-55.

Duan, C., Meng, X., Meng, J., Khan, M. I. H., Dai, 1., Khan, A., An, X., Zhang, J., Huq, T. and Ni, Y. 2019. Chitosan as a preservative for fruits and vegetables: a review on chemistry and antimicrobial properties. J. Bioresour. Bioprod. 4:11-21.

El-Sayed, S. M. and Mahdy, M. E. 2015. Effect of chitosan on root-knot nematode, Meloidogyne javanica on tomato plants. Int. J. ChemTech Res. 7:1985-1992.

Eweis, M., Elkholy, S. S. and Elsabee, M. Z. 2006. Antifungal efficacy of chitosan and its thiourea derivatives upon the growth of some sugar-beet pathogens. Int. J. Biol. Macromol. 38:1-8.

Fan, Z., Qin, Y., Liu, S., Xing, R., Yu, H. and Li, P. 2020. Chitosan oligosaccharide fluorinated derivative control rootknot nematode (Meloidogyne incognita) disease based on the multi-effcacy strategy. Mar. Drugs 18:273.

Feofilova, E. P., Sergeeva, Y. E., Mysyakina, I. S. and Bokareva, D. A. 2015. Lipid composition in cell walls and in mycelial and spore cells of mycelial fungi. Mikrobiologiia 84:204-211 (in Russian).

Food and Agriculture Organization of the United Nations. 2017. The future of food and agriculture: trends and challenges. URL http://www.fao.org/3/i6583e/i6583e.pdf [1 October 2021].

Gupta, P. K. 2018. Toxicity of fungicides. In: Veterinary toxicol- 
ogy: basic and clinical principles, 3rd ed., ed. by R. C. Gupta, pp. 569-580. Academic Press, London, UK.

Heras, A., Rodríguez, N. M, Ramos, V. M. and Agulló, E. 2001. $\mathrm{N}$-methylene phosphonic chitosan: a novel soluble derivative. Carbohydr. Polym. 44:1-8.

Hou, Y.-P., Qu, X.-P., Mao, X.-W., Kuang, J., Duan, Y.-B., Song, X.-S., Wang, J.-X., Chen, C.-J. and Zhou, M.-G. 2018. Resistance mechanism of Fusarium fujikuroi to phenamacril in the field. Pest Manag. Sci. 74:607-616.

Howlett, N. G. and Avery, S. V. 1997. Induction of lipid peroxidation during heavy metal stress in Saccharomyces cerevisiae and influence of plasma membrane fatty acid unsaturation. Appl. Environ. Microbiol. 63:2971-2976.

Ippólito, S. D., Mendieta, J. R., Terrile, M. C., Tonón, C. V., Mansilla, A. Y., Colman, S., Albertengo, L., Rodríguez, M. S. and Casalongué, C. A. 2017. Chitosan as source for pesticide formulations. In: Biological activities and application of marine polysaccharides, ed. by E. Shalaby, pp. 3-15. IntechOpen, London, UK.

Kalaiarasan, P., Lakshmanan, P., Rajendran, G. and Samiyappan, R. 2006. Chitin and chitinolytic biocontrol agents for the management of root knot nematode, Meloidogyne arenaria in groundnut (Arachis hypogaea L.) cv. Co3. Indian J. Nematol. 36:181-186.

Kim, H.-S., Kim, J.-E., Frailey, D., Nohe, A., Duncan, R., Czymmek, K. J. and Kang, S. 2015. Roles of three Fusarium oxysporum calcium ion $\left(\mathrm{Ca}\left({ }^{2+}\right)\right)$ channels in generating $\mathrm{Ca}\left({ }^{2+}\right)$ signatures and controlling growth. Fungal Genet. Biol. 82:145157.

Kim, H.-S., Kim, J.-E., Son, H., Frailey, D., Cirino, R., Lee, Y.W., Duncan, R., Czymmek, K. J. and Kang, S. 2018. Roles of three Fusarium graminearum membrane $\mathrm{Ca}^{2+}$ channels in the formation of $\mathrm{Ca}^{2+}$ signatures, growth, development, pathogenicity and mycotoxin production. Fungal Genet. Biol. 111:3046

Laluk, K. and Mengiste, T. 2010. Necrotroph attacks on plants: wanton destruction or covert extortion? Arabidopsis Book 8:e0136.

Laxalt, A. M., Raho, N., Have, A. T. and Lamattina, L. 2007. Nitric oxide is critical for inducing phosphatidic acid accumulation in xylanase-elicited tomato cells. J. Biol. Chem. 282:21160-21168.

Liu, W., Qin, Y., Liu, S., Xing, R., Yu, H., Chen, X., Li, K. and Li, P. 2018. Synthesis, characterization and antifungal efficacy of chitosan derivatives with triple quaternary ammonium groups. Int. J. Biol. Macromol. 114:942-949.

Lopez-Moya, F., Martin-Urdiroz, M., Oses-Ruiz, M., Were, V. M., Fricker, M. D., Littlejohn, G., Lopez-Llorca, L. V. and Talbot, N. J. 2021. Chitosan inhibits septin-mediated plant infection by the rice blast fungus Magnaporthe oryzae in a protein kinase C and Nox1 NADPH oxidase-dependent manner. New Phytol. 230:1578-1593.

Malerba, M. and Cerana, R. 2018. Recent advances of chitosan applications in plants. Polymers 10:118.
Maluin, F. N. and Hussein, M. Z. 2020. Chitosan-based agronanochemicals as a sustainable alternative in crop protection. Molecules 25:1611.

Mendieta, J. R., Pagano, M. R., Muñoz, F. F., Daleo, G. R. and Guevara, M. G. 2006. Antimicrobial activity of potato aspartic proteases (StAPs) involves membrane permeabilization. Microbiology 152:2039-2047.

Novo, D. J., Perlmutter, N. G., Hunt, R. H. and Shapiro, H. M. 2000. Multiparameter flow cytometric analysis of antibiotic effects on membrane potential, membrane permeability, and bacterial counts of Staphylococcus aureus and Micrococcus luteus. Antimicrob. Agents Chemother. 44:827-834.

Plascencia-Jatomea, M., Viniegra, G., Olayo, R., Castillo-Ortega, M. M. and Shirai, K. 2003. Effect of chitosan and temperature on spore germination of Aspergillus niger. Macromol. Biosci. 3:582-586.

Prins, T. W., Tudzynski, P., von Tiedemann, A., Tudzynski, B., Ten Have, A., Hansen, M. E., Tenberge, K. and van Kan, J. A. L. 2000. Infection strategies of Botrytis cinerea and related necrotrophic pathogens. In: Fungal pathology, ed. by J. W. Kronstad, pp. 33-64. Springer, Dordrecht, Netherlands.

Qin, Y., Xing, R., Liu, S., Yu, H., Li, K., Hu, L. and Li, P. 2014. Synthesis and antifungal properties of (4-tolyloxy)-pyrimidyl$\alpha$-aminophosphonates chitosan derivatives. Int. J. Biol. Macromol. 63:83-91.

Qiu, J., Xu, J. and Shi, J. 2014. Molecular characterization of the Fusarium graminearum species complex in Eastern China. Eur. J. Plant Pathol. 139:811-823.

Rabea, E. I., Badawy, M. E.-T, Stevens C. V., Smagghe G. and Steurbaut, W. 2003. Chitosan as antimicrobial agent: applications and mode of action. Biomacromolecules 4:1457-1465.

Radtke, W. and Escande, A. 1973. Pathogenicity of cepas from the Fusarium collection on Solanum tuberosum cultivars. Rev. Fac. Agron. 49:62-70.

Rambo, G. W. and Bean, G. A. 1969. Fatty acids of the mycelia and conidia of Fusarium oxysporum and Fusarium roseum. Can. J. Microbiol. 15:967-968.

Ramos, V. M., Rodríguez, N. M., Díaz, M. F., Rodríguez, M. S., Heras, A. and Agulló, E. 2003. $N$-methylene phosphonic chitosan. Effect of preparation methods on its properties. Carbohydr. Polym. 52:39-46.

Rioux, D., Jacobi, V., Simard, M. and Hamelin, R. C. 2000. Structural changes of spores of tree fungal pathogens after treatment with the designed antimicrobial peptide D2A21. Can. J. Bot. 78:462-471.

Sukenik, S. C., Karuppanan, K., Li, Q., Lebrilla, C. B., Nandi, S. and McDonald, K. A. 2018. Transient recombinant protein production in glycoengineered Nicotiana benthamiana cell suspension culture. Int. J. Mol. Sci. 19:1205.

Terrile, M. C., Mansilla, A. Y., Albertengo, L., Rodríguez, M. S. and Casalongué, C. A. 2015. Nitric-oxide-mediated cell death is triggered by chitosan in Fusarium eumartii spores. Pest. Manag. Sci. 71:668-674.

Thordal-Christensen, H., Zhang, Z., Wei, Y. and Collinge, D. B. 
1997. Subcellular localization of $\mathrm{H}_{2} \mathrm{O}_{2}$ in plants. $\mathrm{H}_{2} \mathrm{O}_{2}$ accumulation in papillae and hypersensitive response during the barley-powdery mildew interaction. Plant J. 11:1187-1194.

Tikhonov, V. E., Stepnova, E. A., Babak, V. G., Yamskov, I. A., Palma-Guerrero, J., Jansson, H.-B., Lopez-Llorca, L. V., Salinas, J., Gerasimenko, D. V., Avdienko, I. D. and Varlamov, V. P. 2006. Bactericidal and antifungal activities of a low molecular weight chitosan and its N-/2(3)-(dodec-2-enyl) succinoyl/-derivatives. Carbohydr. Polym. 64:66-72.

Verlee, A., Mincke, S. and Stevens, C. V. 2017. Recent developments in antibacterial and antifungal chitosan and its derivatives. Carbohydr. Polym. 164:268-283.

Wang, W., Xue, C. and Mao, X. 2020. Chitosan: structural modification, biological activity and application. Int. J. Biol. Macromol. 164:4532-4546.

Wei, L., Tan, W., Wang, G., Li, Q., Dong, F. and Guo, Z. 2019. The antioxidant and antifungal activity of chitosan derivatives bearing Schiff bases and quaternary ammonium salts. Carbohydr. Polym. 226:115256.

Westerdahl, B. B., Carlson, H. L., Grant, J., Radewald, J. D.,
Welch, N., Anderson, C. A., Darso, J., Kirby, D. and Shibuya, F. 1992. Management of plant-parasitic nematodes with a chitin-urea soil amendment and other materials. J. Nematol. 24:669-680.

Younes, I. and Rinaudo, M. 2015. Chitin and chitosan preparation from marine sources. Structure, properties and applications. Mar. Drugs 13:1133-1174.

Zhang, J., Tan, W., Li, Q., Dong, F. and Guo, Z. 2020. Synthesis and characterization of $\mathrm{N}, \mathrm{N}, \mathrm{N}$-trimethyl-O-(ureidopyridinium) acetyl chitosan derivatives with antioxidant and antifungal activities. Mar. Drugs 18:163.

Zhou, M. G. and Wang, J. X. 2001. Study on sensitivity base-line of Fusarium graminearum to carbendazim and biological characters of MBC-resistant strains. Acta Phytopathol. Sin. 31:365-367 (in Chinese).

Zhu, D. W., Bo, J. G., Zhang, H. L., Liu, W. G., Leng, X. G., Song, C. X., Yin, Y. J., Song, L. P., Liu, L. X., Mei, L., Li, X. L., Zhang, Y. and Yao, K. D. 2007. Synthesis of $N$-methylene phosphonic chitosan (NMPCS) and its potential as gene carrier. Chin. Chem. Lett. 18:1407-1410. 